\title{
Evaluation of air pollution tolerance index of certain plant species grown alongside Parwanoo to Solan National Highway- 22 in Himachal Pradesh, India
}

\author{
Navjot Singh Kaler $^{*}$, S. K. Bhardwaj ${ }^{2}$ and R.K. Gupta ${ }^{3}$ \\ ${ }^{1,2}$ Department of Environmental Science, Dr Y.S. Parmar UHF, Nauni, Solan- 173230 (H.P.), INDIA \\ ${ }^{3}$ Department of Basic Science, Dr Y.S. Parmar UHF, Nauni, Solan- 173230 (H.P.), INDIA \\ "Corresponding author. E-mail: kalernavjot8888@gmail.com
}

Received: March 18, 2016; Revised received: November 3, 2016; Accepted: January 20, 2017

\begin{abstract}
The study examined the Air Pollution Tolerance Index (APTI) of selected plant species growing along national highway-22 from Parwanoo to Solan, falling in Solan district of Himachal Pradesh, India. Four species namely Grewia optiva, Toona ciliata, Melia azedarach and Woodfordia floribunda of uniform size, age, spread and common in occurrence on both sides of the highway are selected. Leaf samples were collected from selected species and used to estimate four physiological and biochemical parameters, namely; leaf relative water content (RWC), ascorbic acid content (AA), total leaf chlorophyll (TChl) and leaf extract pH were used to compute the APTI values. The trend of APTI recorded for various species was Melia azedarach (18.37) > Grewia optiva (8.77) > Woodfordia floribunda (7.43) > Toona ciliata (6.82). The APTI also varied with seasons of the year. The highest APTI was noticed in rainy followed by winter and summer season. The study indicated Melia azedarach as most tolerant and Toona ciliata as most sensitive species to air pollution.
\end{abstract}

Keywords: Air pollution tolerance index (APTI), Melia azedarach, Toona ciliata, Grewia optiva, Woodfordia floribunda

\section{INTRODUCTION}

Air pollution is a major problem arising mainly from industrialization, unplanned urbanisation, alarming increase in vehicle fleet and population growth which become a serious environmental stress to plants during the last few decades (Rajput and Agarwal, 2004). The particulates and gaseous pollutants, cause serious setbacks to the overall physiology of plants (Das and Prasad, 2010). The impact of air pollution on plant species is one of the major ecological issues as plants play an important role in monitoring and maintaining the ecological balance by actively participating in the cycling of nutrients and gases, provide enormous leaf area for the impringement, absorption and accumulation of air pollutants to reduce the pollution level in the air environment.

Sensitivity and response of plants to air pollutants is variable and are considers for investigation of effect of auto exhaust pollutants. The most obvious damage occurs in the leaves which include chlorosis, necrosis and epinasty (Prasad and Choudhury, 1992). The response of plants to air pollution may provide a simple method of monitoring air pollutants as well as providing the pollution abatement measures. The plant species which are more sensitive act as biological indicators of air pollution. Singh and Rao (1983) have suggested a method of determining Air Pollution Tolerance Index (APTI) by synthesizing the values of four different biochemical parameters i.e. leaf extract, ascorbic acid, total chlorophyll and relative water contents. Air pollution tolerance index has been used by landscapers to select and rank plant species in their order of tolerance to air pollution (Liu and Ding, 2008). So the present monitoring work was undertaken to determine the APTI values of selected plant species which are commonly occurred on the both sides of national highway-22 from Parwanoo to Solan. The study will also identify the plant species which are tolerant to the prevailing atmospheric conditions.

\section{MATERIALS AND METHODS}

Study area: The entire study area extended from Parwanoo to Solan, geographically located in Solan district which lies between North latitude $30^{\circ} 44^{\prime} 53^{\prime \prime}$ to $31^{\circ} 22^{\prime} 01^{\prime \prime}$ and East longitude $76^{\circ} 36^{\prime} 10^{\prime \prime}$ to $77^{\circ} 15^{\prime} 14^{\prime \prime}$. The total distance of National Highway between Parwanoo to Solan is $41 \mathrm{kms}$. The National Highway on the way to Shimla, a famous tourist place is subjected to heavy traffic load. The climate of the district is sub-tropical in the valley and tends to be temperate in the hilltops. Average annual rainfall in the district is about $1100 \mathrm{~mm}$ with average of 64 rainy days and Mean maximum and minimum temperature ranges 
between $34^{\circ} \mathrm{C}$ and $4^{\circ} \mathrm{C}$. The Parwanoo-Solan national highway falling in Solan district of Himachal Pradesh is on the hilly terrain having loose strata and generally moderately to steeply sloped with number of curves with altitude ranging from 350 to 1800 meter above mean sea level.

Sampling: For conducting studies the whole area was divided in two parts, i) Parwanoo to Dharmpur ii) Dharmpur to Solan. The study was conducted during three seasons mainly winter (November, 2011), summer (May, 2012) and rainy (August, 2012). Four plant species viz. Woodfordia floribunda, Toona ciliata, Melia azedarach and Grewia optiva were selected at two distances (D1: 0-5 $\mathrm{m}$ and D2: 5-10 m) on the both sides of road for the present investigation. The plants selected for study were uniform with respect to their diameter at breast height (dbh), crown spread and were common in their occurrence on both sides of the highway. The relevant characteristic of these plants are shown in Table 1.

Biochemical analysis: Fully matured leaves from trees were collected in morning hours at diameter breast height $(\mathrm{DBH})$ and from the shrubs of almost same height and care was taken so that the samples from study site were collected from plants growing in isoecological conditions. Fresh leaves were taken to the laboratory in ice box and were analyzed for total chlorophyll (Hiscox and Israeistam, 1979), ascorbic acid (A.O.A.C., 1980), leaf extract pH (Singh and Rao, 1983) and relative water content (Turner, 1981). By using the above parameters the air pollution tolerance index was computed by the method suggested by Singh and Rao (1983) using the equation.

$$
\mathrm{APTI}=\frac{[\mathrm{A}(\mathrm{T}+\mathrm{P})]+\mathrm{R}}{10}
$$

Where: $\mathrm{A}$ is ascorbic acid $\left(\mathrm{mg} \mathrm{g}^{-1}\right)$ of leaf sample, $\mathrm{T}$ is total chlorophyll $\left(\mathrm{mg} \mathrm{g}^{-1}\right)$ of leaf sample, $\mathrm{P}$ is leaf extract $\mathrm{pH}$ of leaf sample, $\mathrm{R}$ is relative water content (\%) of leaf sample.

\section{RESULTS AND DISCUSSION}

The vegetation nearby national highway is exposed to dust pollution and chronic concentration of gaseous pollutants, which may affect the biochemical make up, and tolerance capability of plants to the air pollution. The biochemical characteristics and the APTI for plants are shown in Tables 2, 3, 4, 5 and 6

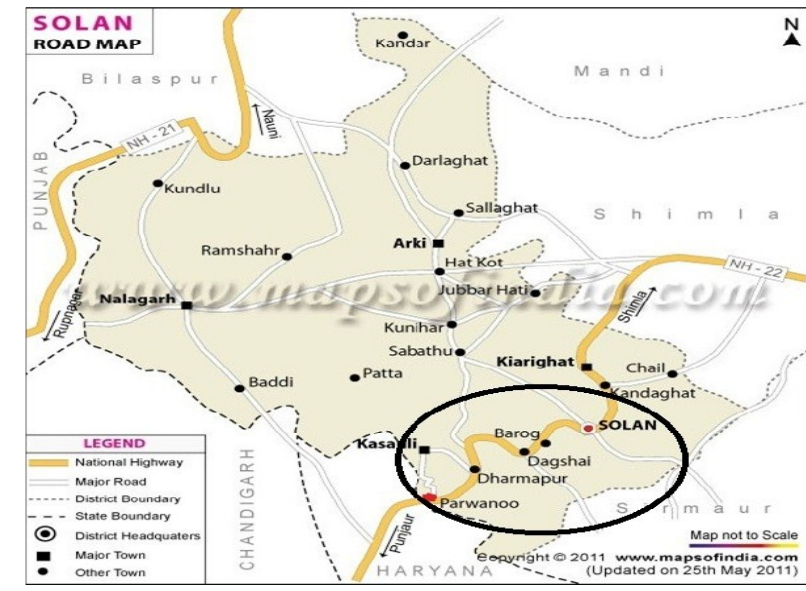

Fig. 1. Map showing the study area.. Source: (www.mapsofindia.com).

respectively.

The total Chlorophyll content (Table 2) varied with species and seasons. The highest chlorophyll content was found in $M$. azedarach $\left(7.18 \mathrm{mg} \mathrm{g}^{-1}\right)$ followed by W. floribunda (4.91 $\left.\mathrm{mg} \mathrm{g}^{-1}\right)$, G. optiva $\left(3.54 \mathrm{mg} \mathrm{g}^{-1}\right)$ and $T$. ciliata $\left(2.18 \mathrm{mg} \mathrm{g}^{-1}\right)$. The chlorophyll content in all the plants varied with the tolerance as well as sensitivity of the plant species to pollution load (Joshi et al., 1993) and the high level of automobile pollution decreases chlorophyll content in higher plants near roadsides (Tripathi and Gautam, 2007). The chlorophyll content was observed highest among the plant species during rainy $\left(4.90 \mathrm{mg} \mathrm{g}^{-1}\right)$ followed by winter ( $\left.3.84 \mathrm{mg} \mathrm{g}^{-1}\right)$ and lowest in the summer season (3.63 $\left.\mathrm{mg}^{-1}\right)$. Similar results were obtained by Jyothi and Jaya (2010) who reported high chlorophyll content in plant species during rainy season which may be due to the washout of dust particles from the leaf surface, low level of pollution and water content of soil followed by winter may be due to the high pollution level, temperature stress, low sunlight intensity and short photoperiod and summer season may be due to high sunlight, reduce moisture content and high wind speed.

The concentration of ascorbic acid (Table 3) varied from species to species and season to season. The highest ascorbic acid content was found in M. azedarach $\left(8.40 \mathrm{mg} \mathrm{g}^{-1}\right)$, G. optiva $\left(3.62 \mathrm{mg} \mathrm{g}^{-1}\right)$, $W$. floribunda $\left(2.79 \mathrm{mg} \mathrm{g}^{-1}\right)$ and lowest in T. ciliata $\left(2.13 \mathrm{mg} \mathrm{g}^{-1}\right)$ indicating that the species with high ascorbic content is tolerant and lower ascorbic acid is sensitive to pollution (Prajapati and Tripathi, 2008)

Table 1. Characteristics of selected plants at study site from Parwanoo to Solan on national highway-22, India.

\begin{tabular}{|c|c|c|c|c|c|}
\hline Name of Plant & Family & Common name & Habit & Leaf shape & $\begin{array}{l}\text { Average Plant height } \\
\text { approx. (m) }\end{array}$ \\
\hline Woodfordia floribunda & Lythraceae & Dhatki, Dhawai & Shrub & Elliptical & 3 \\
\hline Toona ciliata & Meliaceae & $\begin{array}{l}\text { Toon, Indian } \\
\text { mahogany }\end{array}$ & Tree & $\begin{array}{l}\text { Elliptical } \\
\text { (Leaflet-Imparipinnate) }\end{array}$ & 25 \\
\hline Melia azedarach & Meliaceae & $\begin{array}{l}\text { Drek, } \\
\text { Bead tree }\end{array}$ & Tree & $\begin{array}{l}\text { Elliptical } \\
\text { (Leaflet-Tripinnate) }\end{array}$ & 18 \\
\hline Grewia optiva & Tiliaceae & Dhaman, Biul & Tree & Ovate & 12 \\
\hline
\end{tabular}


Table 2. Season wise leaf chlorophyll content $\left(\mathrm{mg} \mathrm{g}^{-1}\right)$ of selected plant species in relation to distance from roadside on Parwanoo to Solan national highway- 22, India.

\begin{tabular}{|c|c|c|c|c|c|c|c|c|c|c|c|c|}
\hline \multirow{3}{*}{ Name of Species } & \multicolumn{9}{|c|}{ Season } & \multirow{3}{*}{ D1* } & \multirow{3}{*}{ D2* } & \multirow{3}{*}{ Mean } \\
\hline & \multicolumn{3}{|c|}{ Rainy } & \multicolumn{3}{|c|}{ Winter } & \multicolumn{3}{|c|}{ Summer } & & & \\
\hline & D1* & D2* & Mean & D1* & D2* & Mean & D1* & D2* & Mean & & & \\
\hline Woodfordia floribunda & 5.36 & 5.37 & 5.36 & 4.84 & 4.83 & 2.68 & 4.54 & 4.54 & 4.54 & 4.92 & 4.91 & 4.91 \\
\hline Toona ciliata & 2.62 & 2.61 & 2.62 & 2.10 & 2.09 & 2.09 & 1.83 & 1.82 & 1.82 & 2.18 & 2.17 & 2.18 \\
\hline Melia azedarach & 7.64 & 7.65 & 7.64 & 7.10 & 7.11 & 7.11 & 6.81 & 6.79 & 6.80 & 7.18 & 7.18 & 7.18 \\
\hline Grewia optiva & 3.99 & 3.98 & 3.98 & 3.48 & 3.47 & 3.47 & 3.19 & 3.14 & 3.17 & 3.55 & 3.53 & 3.54 \\
\hline Mean & 4.90 & 4.90 & 4.90 & 4.38 & 4.38 & 3.84 & 4.09 & 4.07 & 3.63 & 4.46 & 4.45 & \\
\hline
\end{tabular}

$* \mathrm{D} 1=0-5 \mathrm{~m}$ and $\mathrm{D} 2=5-10 \mathrm{~m}$ are distances from the roadside

Table 3. Season wise leaf ascorbic acid content $\left(\mathrm{mg} \mathrm{g}^{-1}\right)$ of selected plant species in relation to distance from roadside on Parwanoo to Solan national highway- 22, India.

\begin{tabular}{|c|c|c|c|c|c|c|c|c|c|c|c|c|}
\hline \multirow{3}{*}{ Name of Species } & \multicolumn{9}{|c|}{ Season } & \multirow{3}{*}{ D1* } & \multirow{3}{*}{ D2* } & \multirow{3}{*}{ Mean } \\
\hline & \multirow{2}{*}{\multicolumn{3}{|c|}{$\frac{\text { Rainy }}{22^{*} \quad \text { Mean }}$}} & \multicolumn{3}{|c|}{ Winter } & \multicolumn{3}{|c|}{ Summer } & & & \\
\hline & & & & D1* & D2* & Mean & D1* & D2* & Mean & & & \\
\hline Woodfordia floribunda & 2.29 & 2.31 & 2.30 & 2.81 & 2.84 & 2.83 & 3.25 & 3.26 & 3.25 & 2.79 & 2.80 & 2.79 \\
\hline Toona ciliata & 1.62 & 1.63 & 1.62 & 2.17 & 2.17 & 2.17 & 2.60 & 2.60 & 2.60 & 2.13 & 2.13 & 2.13 \\
\hline Melia azedarach & 7.88 & 7.88 & 7.88 & 8.44 & 8.44 & 8.44 & 8.87 & 8.87 & 8.87 & 8.39 & 8.40 & 8.40 \\
\hline Grewia optiva & 3.12 & 3.11 & 3.12 & 3.67 & 3.65 & 3.66 & 4.09 & 4.08 & 4.09 & 3.63 & 3.61 & 3.62 \\
\hline Mean & 3.73 & 3.73 & 3.73 & 4.27 & 4.27 & 4.27 & 4.70 & 4.70 & 4.18 & 4.23 & 4.24 & \\
\hline
\end{tabular}

$* \mathrm{D} 1=0-5 \mathrm{~m}$ and $\mathrm{D} 2=5-10 \mathrm{~m}$ are distances from the roadside

and also ascorbic acid content was recorded highest among the plant species during winter season $(4.27 \mathrm{mg}$ $\left.\mathrm{g}^{-1}\right)$ followed by summer season $\left(4.18 \mathrm{mg} \mathrm{g}^{-1}\right)$ and lowest in the rainy season $\left(3.73 \mathrm{mg} \mathrm{g}^{-1}\right)$.

Variation was observed in $\mathrm{pH}$ of leaf extract (Table 4) of different species during different seasons. The highest $\mathrm{pH}$ was recorded in the rainy season followed by winter season and lowest in summer season. Among selected plant species leaf extract $\mathrm{pH}$ was highest in $M$. azedarach (7.66) followed by G. optiva (6.75),
T. ciliata (6.60) and lowest in $W$. floribunda (5.85) indicating that $M$. azedarach with high $\mathrm{pH}$ is tolerant to acidic pollutants and $W$. floribunda having lowest $\mathrm{pH}$ is sensitive. The present results are in line with Jyothi and Jaya (2010) who reported that sensitive species has less $\mathrm{pH}$ and also the decline in $\mathrm{pH}$ is greater in sensitive species in the presence of an acidic pollutant and also reported the maximum $\mathrm{pH}$ during monsoon season with gradual reduction through winter and minimum in summer.

Table 4. Season wise leaf extract $\mathrm{pH}$ of selected plant species in relation to distance from roadside on Parwanoo to Solan national highway- 22, India.

\begin{tabular}{|c|c|c|c|c|c|c|c|c|c|c|c|c|}
\hline \multirow{3}{*}{ Name of Species } & \multicolumn{9}{|c|}{ Season } & \multirow{3}{*}{ D1* } & \multirow{3}{*}{ D2* } & \multirow{3}{*}{ Mean } \\
\hline & \multicolumn{4}{|c|}{ Rainy } & \multicolumn{2}{|c|}{ Winter } & \multicolumn{3}{|c|}{ Summer } & & & \\
\hline & D1* & D2* & Mean & D1* & D2* & Mean & D1* & D2* & Mean & & & \\
\hline Woodfordia floribunda & 6.21 & 6.24 & 6.23 & 5.83 & 5.86 & 5.84 & 5.46 & 5.50 & 5.48 & 5.83 & 5.87 & 5.85 \\
\hline Toona ciliata & 7.05 & 6.96 & 7.00 & 6.66 & 6.58 & 6.62 & 6.15 & 6.22 & 6.19 & 6.62 & 6.59 & 6.60 \\
\hline Melia azedarach & 8.19 & 7.96 & 8.07 & 7.80 & 7.35 & 7.57 & 7.45 & 7.21 & 7.33 & 7.81 & 7.51 & 7.66 \\
\hline Grewia optiva & 7.11 & 7.15 & 7.13 & 6.72 & 6.76 & 6.74 & 6.37 & 6.40 & 6.39 & 6.73 & 6.77 & 6.75 \\
\hline Mean & 7.14 & 7.08 & 7.11 & 6.75 & 6.64 & 6.69 & 6.36 & 6.33 & 5.64 & 6.75 & 6.68 & \\
\hline
\end{tabular}

$* \mathrm{D} 1=0-5 \mathrm{~m}$ and $\mathrm{D} 2=5-10 \mathrm{~m}$ are distances from the roadside

Table 5. Season wise leaf relative water content (\%) of selected plant species in relation to distance from roadside on Parwanoo to Solan national highway- 22, India.

\begin{tabular}{|c|c|c|c|c|c|c|c|c|c|c|c|c|}
\hline \multirow{3}{*}{$\begin{array}{l}\text { Name of } \\
\text { Species }\end{array}$} & \multicolumn{9}{|c|}{ Season } & \multirow{3}{*}{ D1* } & \multirow{3}{*}{ D2* } & \multirow{3}{*}{ Mean } \\
\hline & \multirow{2}{*}{\multicolumn{3}{|c|}{$\frac{\text { Rainy }}{2 * \quad \mathrm{~N}}$}} & \multicolumn{3}{|c|}{ Winter } & \multicolumn{3}{|c|}{ Summer } & & & \\
\hline & & & & D1* & D2* & Mean & D1* & D2* & Mean & & & \\
\hline $\begin{array}{l}\text { Woodfordia } \\
\text { floribunda }\end{array}$ & 5642 & 58.45 & 57.43 & 39.65 & 41.65 & 40.65 & 34.82 & 35.87 & 35.35 & 43.63 & 45.32 & 44.48 \\
\hline Toona ciliata & 61.63 & 63.92 & 62.77 & 44.48 & 47.15 & 45.81 & 39.34 & 42.07 & 40.70 & 48.48 & 51.05 & 49.76 \\
\hline Melia azedarach & 73.11 & 71.39 & 72.25 & 56.36 & 54.63 & 55.49 & 50.98 & 49.56 & 50.27 & 60.15 & 58.52 & 59.34 \\
\hline Grewia optiva & 61.34 & 65.79 & 63.56 & 44.67 & 49.07 & 46.87 & 39.39 & 43.86 & 41.63 & 48.47 & 52.91 & 50.69 \\
\hline Mean & 63.13 & 64.89 & 64.01 & 46.29 & 48.12 & 47.21 & 41.13 & 42.84 & 37.32 & 50.18 & 51.95 & \\
\hline
\end{tabular}

$* \mathrm{D} 1=0-5 \mathrm{~m}$ and $\mathrm{D} 2=5-10 \mathrm{~m}$ are distances from the roadside 
Table 6. Season wise air pollution tolerance index (APTI) of selected plant species in relation to distance from roadside on Parwanoo to Solan national highway- 22, India.

\begin{tabular}{|c|c|c|c|c|c|c|c|c|c|c|c|c|}
\hline \multirow{3}{*}{ Name of Species } & \multicolumn{9}{|c|}{ Season } & \multirow{3}{*}{ D1* } & \multirow{3}{*}{ D2* } & \multirow{3}{*}{ Mean } \\
\hline & \multicolumn{3}{|c|}{ Rainy } & \multicolumn{3}{|c|}{ Winter } & \multicolumn{3}{|c|}{ Summer } & & & \\
\hline & D1* & D2* & Mean & D1* & D2* & Mean & D1* & D2* & Mean & & & \\
\hline Woodfordia & & & & & & & & & & & & \\
\hline floribunda & 8.30 & 8.53 & 8.41 & 6.97 & 7.20 & 7.08 & 6.73 & 6.86 & 6.80 & 7.33 & 7.53 & 7.43 \\
\hline Toona ciliata & 7.73 & 7.95 & 7.84 & 6.35 & 6.60 & 6.47 & 6.01 & 6.29 & 6.15 & 6.70 & 6.95 & 6.82 \\
\hline Melia azedarach & 19.78 & 19.44 & 19.61 & 18.21 & 17.66 & 17.94 & 17.74 & 17.38 & 17.56 & 18.58 & 18.16 & 18.37 \\
\hline Grewia optiva & 9.60 & 10.04 & 9.82 & 8.21 & 8.64 & 8.42 & 7.85 & 8.28 & 8.06 & 8.55 & 8.98 & 8.77 \\
\hline Mean & 11.35 & 11.49 & 11.42 & 9.93 & 10.02 & 9.98 & 9.58 & 9.70 & 8.57 & 10.29 & 10.41 & \\
\hline
\end{tabular}

$* \mathrm{D} 1=0-5 \mathrm{~m}$ and $\mathrm{D} 2=5-10 \mathrm{~m}$ are distances from the roadside

The study showed highest relative water content (Table 5) in $M$. azedarach $(59.34 \%)$ followed by G. optiva $(50.69 \%)$, T. ciliata $(49.76 \%)$ and lowest in $W$. floribunda $(44.48 \%)$. The relative water content was recorded highest during rainy season (64.01\%) with a decline in the level during winter (47.21\%) and lowest in the summer season $(37.32 \%)$. This is in agreement with the findings of Jyothi and Jaya (2010) who reported that the plant with high relative water content under polluted conditions are tolerant to pollutants and also observed highest relative water content in monsoon season followed by winter and rainy season.

Air pollution tolerant index is an index denotes capability of a plant to combat against air pollution. Plants which have higher index value are tolerant to air pollution and can be caused as sink to mitigate pollution, while plants with low index value show less tolerance and can be used to indicate levels of air pollution. The trend of APTI (Table 6) for different plant species was M. azedarach $(18.37)>G$. optiva $(8.77)>W$. floribun$d a(7.43)>T$. ciliata $(6.82)$. The different plant species shows considerable variation in their susceptibility to air pollution. The plants with high and low APTI can serve as tolerant and sensitive species, respectively. The results are in consonance with the findings of Singh and Rao (1983) who reported that plants which have higher index value are tolerant to air pollution and can be used as sink to control pollution, while plants with low index value show less tolerance and can be used to indicate levels of air pollution. The APTI values varied significantly with different seasons. The highest APTI value was recorded in rainy (11.42) followed by winter (9.98) whereas, lowest was found in summer (8.57) season. The APTI value evaluated for the two distances varied significantly. The maximum APTI (10.41) was found at 5-10 m and minimum (10.29) at $0-5 \mathrm{~m}$. Similar study of air pollution tolerance index was also conducted by Karthiyayini et al. (2005) on different species; Azadirachta indica, amongst trees, Ricinus communis, Bougainvillea spectabilis, Calatropis gigantea, amongst shrubs, Amaranthus virdis, Datura stramonium, amongst herbs, Cucurbita pepo, amongst climbers, Agbaire and Esiefarienrhe (2009) on different species; Emilia Santi- folia, Manihot esculenta, Psidium guayava, Eupatorium odoratum, Impereta cylindrical and Elaesis guineensis, Tripathi et al. (2009) on tree species such as Ficus rumphii, Pongamia pinnata, Alstonia scholaris, Holoptelea integrifolia, Saraca indica, Pithecolobium dulcis, Cassia simea, Bauhinia variegata, Azadirachta indica and Grewelia robusta and Chauhan (2010) on different species like Ficus religiosa, Mangifera indica, Polyalthia longifolia and Delonix regia.

\section{Conclusion}

The present study indicated the suitability of selected plant species as tolerant or sensitive for air pollution as per their APTI values. It can be utilized for roadside plantation, urban plantation and green belt development to reduce the level of air pollution. It was also observed that the biochemical traits of selected species are one of the valuable sensitive indicators of air pollution. The APTI evaluation showed highest tolerance of $M$. azedarach to air pollution and the order of tolerance was $M$. azedarach $>G$. optiva $>$ $W$. floribunda $>T$. ciliata among the selected plant species. Therefore, these plant species may be used as a biodiversity indicator which can alleviate air pollutants. However, more research is necessary on a wide variety of trees, shrubs, and herbs to prepare a biological sensitively map of flora. The vast database would be useful in identifying tolerant plants, sink plants and indicator species for effective air pollution management program.

\section{ACKNOWLEDGEMENTS}

Authors are thankful to the Prof. G.S. Shamet, Dean, College of Forestry, Department of Environmental Sciences, Dr. YS Parmar University of Horticulture and Forestry Nauni (Solan) for providing laboratory and library facility and their kind encouragement.

\section{REFERENCES}

Agbaire, P.O. and Esiefarienrhe, E. (2009). Air pollution tolerance indices (apti) of some plants around Otorogun gas plant in Delta state, Nigeria. Journal of Applied Science and Environmental Management, 13(1):11-14

A.O.A.C. (1980). Official methods of analysis of the analytical chemist, $13^{\text {th }}$ ed. (W. Horwitz, ed.). Association of 
Analytical Chemists, 83: 617-623

Chauhan, A. (2010). Tree as bio indicator of automobile pollution in Dehradun city: A case study. New York Science Journal, 3(6): 88 - 95

Das, S. and Prasad, P. (2010). Seasonal variation in air pollution tolerance indices and selection of plant species for industrial areas of Rourkela. Indian Journal of Environmental Protection, 30(12): 978-988

Hiscox, J.D. and Israelstam, G.F. (1979). A method for the extraction of chlorophyll from leaf tissue without maceration. Canadian Journal of Botany, 57: 1332-1334

Joshi, O.P., Pawar, K. and Wagela, D.K. (1993). Air quality monitoring of Indore city with special reference to $\mathrm{SO}_{2}$ and tree barks pH. Journal of Environmental Biology, 14(2): $157-162$

Jyothi, J.S. and Jaya, D.S. (2010). Evaluation of air pollution tolerance index of selected plant species along roadsides in Thiruvanthapuram, Kerala. Journal of Environment Biology, 31: 379-386

Karthiyayini, R., Ponnammal, N.R. and Joseph, R. (2005). Air pollution tolerance index of certain plants of Coimbatore- Ooty highyways, near I.T.I area, Coimbatore, Tamilnadu. Pollution Research, 24(2): 363 - 365

Liu, Y. J. and Ding, H. (2008). Variation in air pollution tolerance index of plants near a steel factory: Implication for landscape-plant species selection for industrial areas. Wseas Transactions on Environment and Development, 4: 24 -32

Prajapati, S.K. and Tripathi, B.D. (2008). Anticipated performance index of some tree species considered for green belt development in and around an urban area: a case study of Varanasi City. Indian Journal of Environmental Management, 88(4): 1343-1349

Prasad, D. and Choudhury (1992). Effects of air pollution. In:Misra, S.G. (Ed): Environmental pollution Air, Environmental Pollution and Hazards Series. Venus Publishing House, New Delhi. pp. 58-60

Rajput, M. and Agarwal, M. (2004). Physiological and yield responses of pea plants to ambient air pollution. Indian Journal of Plant Physiology, 9(1): 9-14

Singh, S.K. and Rao, D.N. (1983). Evaluation of the plants for their tolerance to air pollution Proc. Symp on Air Pollution control held at IIT, Delhi. pp 218-224

Tripathi, A.K. and Guatam, M. (2007). Biochemical parameters of plants as indicators of air pollution. Journal of Environmental Biology, 28: 127-132

Tripathi, A.K., Mahima, Tiwari, P.B. and Singh, D. (2009). Assessment of air pollution tolerance index of some trees in Moradabad city, India. Journal of Environmental Biology, 30(4): 545 - 550

Turner, N.C. (1981). Techniques and experimental approaches for the measurement of plant water stress. Plant Soil, 58: 339-366 